\title{
Modular Design of Field Lysimeters for Specific Application Needs
}

\author{
G. von Unold • J. Fank
}

Received: 15 January 2007 / Accepted: 28 September 2007 / Published online: 15 December 2007

(C) Springer Science + Business Media B.V. 2007

\begin{abstract}
In Europe, the use of direct methods using lysimeters for measuring water and solute flow in soils increased in recent years. Large weighable lysimeters are best suitable for obtaining reliable data about seepage water quantity and quality. Field lysimeters - lysimeters built in directly in agriculturally used areas - of high technical standard allow a precise determination of the influence of different cropping systems on groundwater quality. They combine the advantages of true field conditions and laboratory possibilities of varying parameters, handling and maintenance. Due to the specific needs of each application the instrumentation varies. Based on general remarks on the advantages of precise weighing lysimeters four standardized lysimeter configurations are presented. Beside the specific needs of design and setup of lysimeter stations, there is need to define general requirements to enable comparable
\end{abstract}

G. von Unold $(\bowtie)$

UMS Umweltanalytische Messsysteme $\mathrm{GmbH}$,

Gmunder Strasse 37,

81379 München, Germany

e-mail: gvu@ums-muc.de

J. Fank

Institute for Water Resources Management -

Hydrogeology and Geophysics, Joanneum Research,

Elisabethstrasse 16/II,

8010 Graz, Austria results based on standardized basic design and to reduce individual mistakes.

Keywords Field lysimeter - Lysimeter calibration .

Water balance parameters .

Application oriented lysimeter design

\section{Introduction}

The evaluation of lysimeter data allows a much more reliable calculation of the solute load carried towards the groundwater than any other method (Klocke et al. 1993). If the lysimeters weight is recorded in certain time steps, precipitation and seepage water amount is measured separately, actual evapotranspiration can be deduced from their weight change (Young et al. 1996). Due to these characteristics, lysimeters are an excellent tool to derive or calibrate water and solute transport models (Wriedt 2004). Exact information about the soil water balance is needed to quantify solute transfer within the unsaturated zone (Fank 2006). A large weighable Lysimeter is the best method for obtaining reliable data about seepage water quantity and quality. In Europe, the use of direct lysimetry methods (as opposed to measurement of water content and soil water tension in different horizons for determining vertical water flow using soil water models) for measuring water and solute flows in soils increased in recent years. The combination of Lysimeter studies with 
field experiments at different scales opens new possibilities for modeling and management of watersheds (Meissner and Seyfarth 2004).

Lysimeters, well known since nearly one century, ran through a technical revolution the last 10 years. While lysimeters initially measured water drainage only, they are available now as precise tools for any water flux, soil water determination and water balance studies. Also the interfaces to Aquifer and Atmosphere (measurement of dew, fog and rime as shown by Meissner et al. 2007) can be modeled now using precise parameters.

\section{General Remarks on Precise Weighing Monolithic Lysimeters}

Monolithic weighable lysimeters are tools for water balance studies and solute reaction \& flux determination in Hydrology, Climatology, Bioremediation, Soil Science and Agronomy. The different tasks require different application-oriented construction, measurement equipment, and handling as well as data evaluation tools. Thus, each type is aligned to specific needs whereas four types of lysimeters with standardized design will be presented.

Due to the high precision weighing system with a resolution of $0.01 \mathrm{~mm}$ water equivalent and other technical improvements, lysimeters are now usable for precise water measurements and solute flux determination. The measure intervals depend on the measured parameter and its time variance. So it can be necessary to choose it down to several seconds as needed for evapotranspiration (ET) and grass reference evapotranspiration $\left(\mathrm{ET}_{\mathrm{O}}\right)$ determination for short time intervals.

At the agro-hydrological research field in Wagna (Styria, Austria) based on the requirements defined in Fank et al. (2004) precise weighing field lysimeters has been built in 2004 (Fank and Unold 2005). The accuracy of weighing data has been proofed in a calibration experiment on September, 27th 2005. Barbells with exact weights of $0.5,1.0$ and $1.5 \mathrm{~kg}$ respectively have been put on the lysimeter every $3 \mathrm{~min}$. Figure 1 shows the lysimeter weight as a function of the additional mass in comparison to the $1: 1$ line as well as the resulting water balance. During the period 07:30 to 09:00 $33.5 \mathrm{~kg}$ of calibration weights has been added and removed from 09:00 to 10:30. Taking into account the amount of seepage water during calibration, the accordance is very good. The calculated difference of 0.02 and $0.17 \mathrm{~kg}$ respectively is interpreted as the real evapotranspiration from the lysimeter.

To solve the water balance equation, $P+I-\mathrm{ET}-D^{-}$ $\Delta S=0$, we need the following parameters: $P=$ Precip-
Fig. 1 Calibration of the lysimeter weighing system

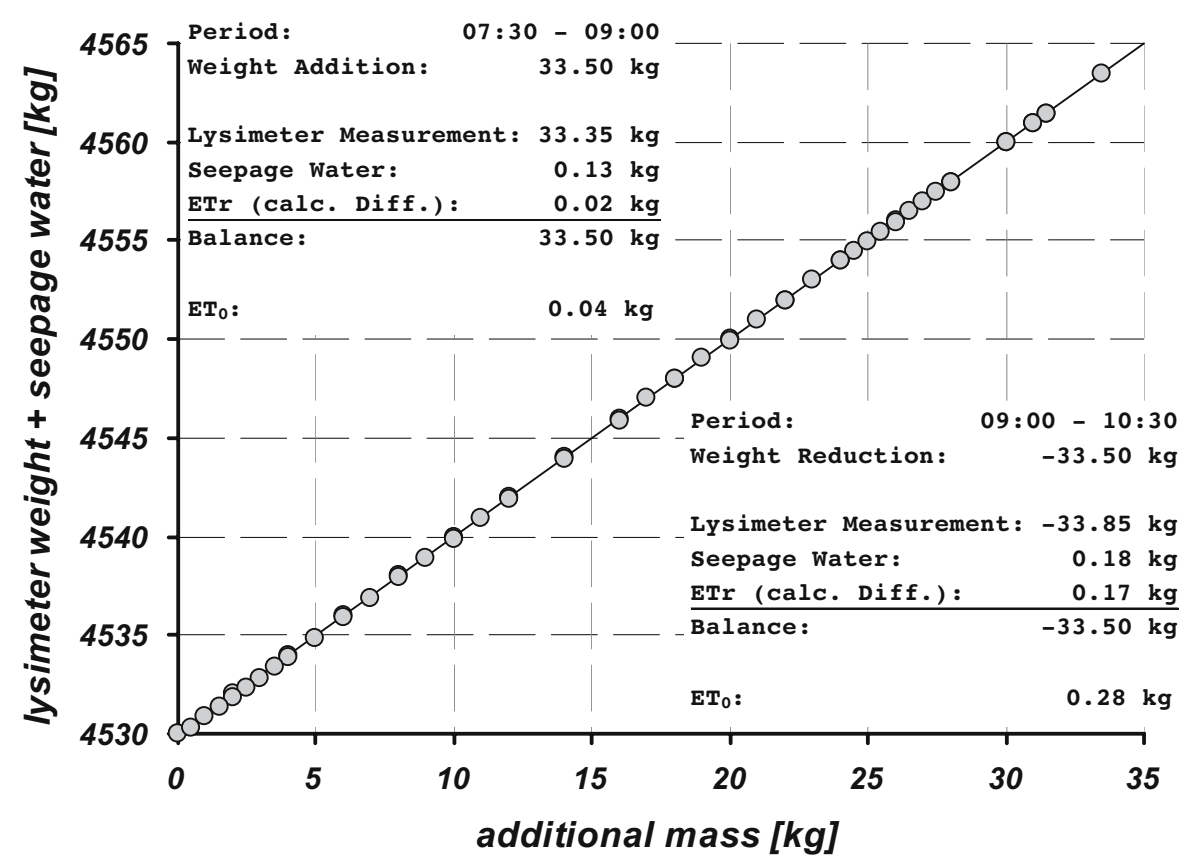


itation, $I=$ Irrigation, $D=$ Drainage water, ET=Evapotranspiration, $\Delta S=$ Change of Water in the monolith. Determination of the water balance parameters from Lysimeter weights - configuration as installed at test field Wagna - is shown as a flow chart in Fig. 2. The recording of the lysimeter weight in an interval of $1 \mathrm{~min}$ and the amount of seepage water as a sum over $10 \mathrm{~min}$ allows the direct determination of all water balance parameters for a plain site with only vertical movement of water. The amount of seepage water is detected using a tipping bucket; therefore there is no continuous recording available. Readings of seepage water amount and of lysimeter weight has to be checked for outside influences. The amount of seepage water has to be interpolated to the time interval of $1 \mathrm{~min}$. Checked and corrected data are stored in a time series data base (DB Time Series).

For this type of data evaluation we assume, that during a certain time interval of $1 \mathrm{~min}$ either precipitation or evapotranspiration occurs. For the time step of $1 \mathrm{~min}$, lysimeter precipitation is determined from the positive change of the weight, real evapotranspiration from the negative change of the weight; both are corrected using the measured amount of seepage water. Following the procedure in Fig. 2 all the parameters of the water balance equation may be determined from data of precise weighing lysimeters.

\section{General Technical Lysimeter Design Description}

The cylindrical stainless steel monolithic lysimeter has a surface of $1 \mathrm{~m}^{2}$ and a monolith depth of $1 \mathrm{~m}$. After excavation in strictly vertical direction - to prohibit preferential flow paths at the border of the lysimeter core - three load cells are situated on a concrete fundament in the pit. The different sensors depending on the lysimeter type are built in and the monolithic lysimeter is placed on the load cells. Three rods allow the adjustment of the Lysimeter in $x-y-z$ direction after finishing the implementation of the Lysimeter and for maintenance purposes. The outer Lysimeter cone is put on the monolithic Lysimeter core with an annular gap of less than $1 \mathrm{~cm}$ at the ground surface. A well for maintenance purposes is situated $2 \mathrm{~m}$ beside the Lysimeter and the pit is refilled with the excavated material in the opposite way of excavation.

Due to the high resolution weighing system, the measure of water fractions is possible with a resolution of $10 \mathrm{~g}$, which is $0.01 \mathrm{~mm}$ of water equivalent. The accuracy is $100 \mathrm{~g}$. The drainage water measurement by a second load cell system or an encapsulated tipping bucket enables high resolution and a stand-alone period of 1 month. The flux is field matrix controlled.

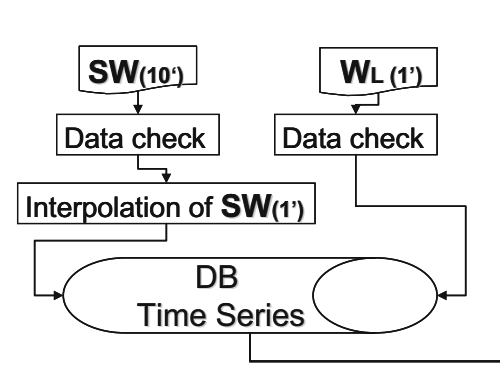

Fig. 2 Flow chart of water balance parameter determination. $S W\left(10^{\prime}\right)=$ amount of seepage water in $10 \mathrm{~min}, W L\left(1^{\prime}\right)=$ Lysimeter weight $\left(\right.$ timestep $\left.=1^{\prime}\right)$, Data check $=$ Procedure on checking data for outside influences, $S W\left(1^{\prime}\right)=$ amount of seepage water in $1 \mathrm{~min}, W s=$ lysimeter weight at the starting time for a certain evaluation period, $W e=$ Lysimeter weight at

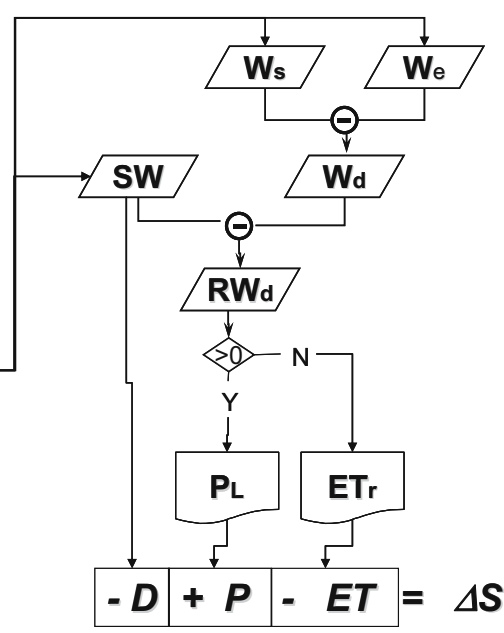

the end time for a certain evaluation period, $W d=$ weight difference, $S W=$ amount of seepage water, $R W d=$ reduced weight difference, $P L=$ Lysimeter precipitation, $E T r=$ real evapotranspiration, $D=$ Drainage, $P=$ Precipitation, $E T=$ Evapotranspiration, $\Delta S=$ storage change in the lysimeter's volume 
The bottom section of the monolithic pillar is formed as a matrix potential area to achieve field comparable fluxes by transmitting the field matrix potential into the Lysimeter. With this water-flux-control-technique, the bottom plate does no more cut off field fluxes but follows them upwards and downwards. To receive the congruent field flux situation, the lysimeters bottom plate got a suction cup rake with a surface of $3,600 \mathrm{~cm}^{2}$. The field water tension, which is measured in $90 \mathrm{~cm}$ depth with an external field tensiometer, and the vacuum applied at the suction cup, are continuously measured. A bidirectional acting pump is controlled to keep the vacuum on the same level as the soil water tension. If the field soil water is recharged by groundwater, the lysimeter will be recharged as well by pumping the adequate amount of water from the drainage vessel into the lysimeter. The water level of the vessel is automatically controlled to keep a water reservoir for the recharge purpose. The basics of the general lysimeter configuration are shown in Fig. 3.

\section{Standardisation of Lysimeter Designs}

Due to the different requirements of Lysimeter applications there is a need on the standardisation of different components of Lysimeter configurations to reduce the costs of production and implementation. The following paragraphs will show four standardized Lysimeter designs for specific applications to implement directly in the field.

\subsection{Hydro-Lysimeter}

The Hydro-Lysimeter as the basic Lysimeter design (Fig. 3) is designed to solve the water balance equation. It measures the weight of the Lysimeter monolith as well as drainage. Precipitation and evapotranspiration may be determined from the change of the lysimeters weight for different time steps (Fig. 2). Precipitation evaluation and drainage measurement enable the determination of groundwa-

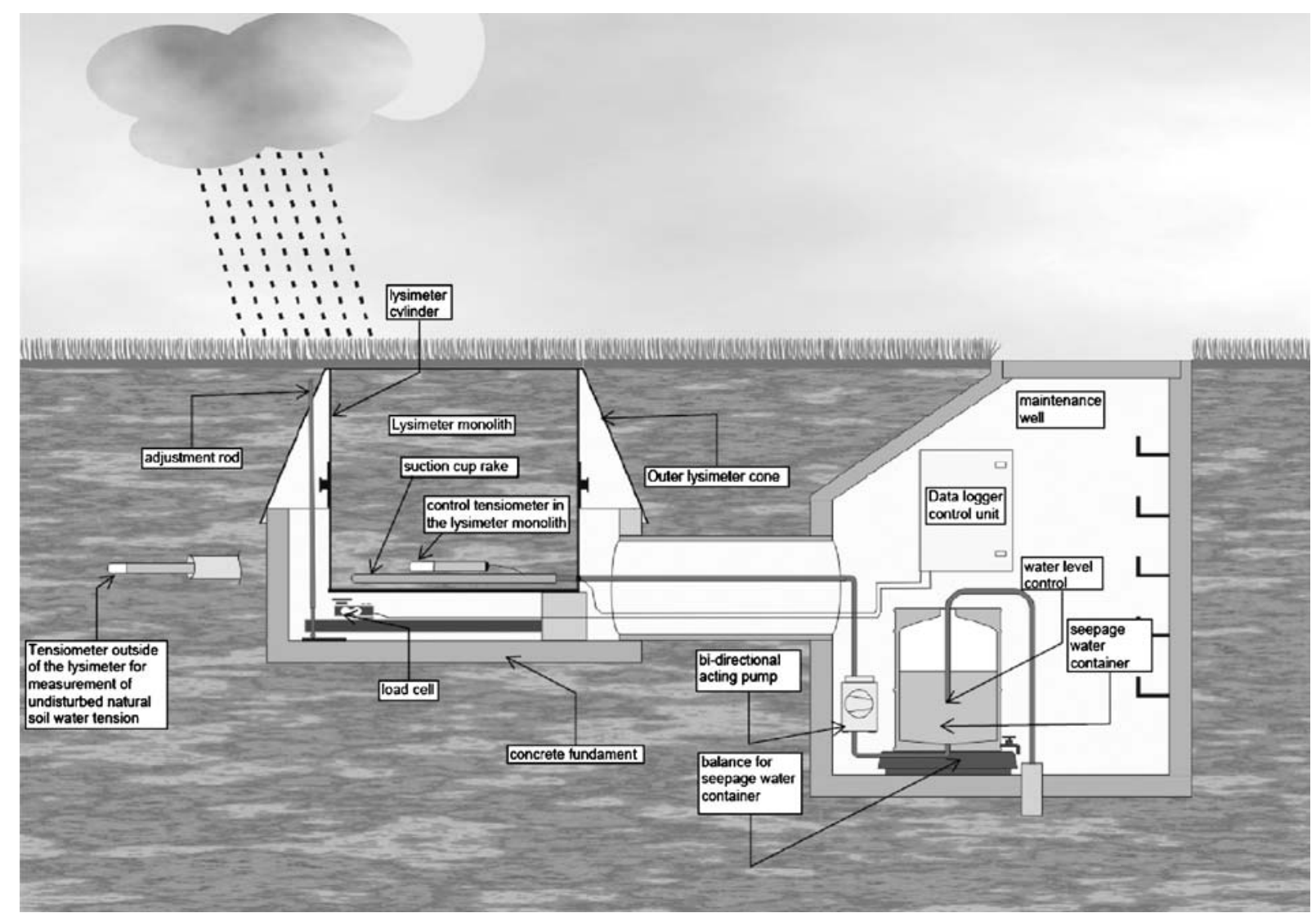

Fig. 3 Schematic sketch of the Hydro-Lysimeter configuration 
ter recharge capacities. Therefore it measures the soil water parameters and their interfaces to atmosphere and aquifer. Input parameters are rain, measured as true amount of water reaching the soil surface (including dew and rime - differentiated from falling precipitation by time dependent comparison with measurements of a standard precipitation gauge) and the water equivalent of snowfall. Output parameters are real Evapotranspiration, and drainage rates.

The accuracy of determination of water balance parameters from the Hydro-Lysimeter as installed at the Wagna agricultural test field is shown in Fig. 4. During the evaluated period no seepage water has been detected, the grass at the Lysimeter was well watered.

Part (a) shows the cumulated sum of grass evapotranspiration determined from lysimeter weights following the procedure shown in Fig. 2 - compared to the cumulated sum of grass-reference evapotranspi- ration over 6 days in July 2006. Grass reference evapotranspiration has been calculated using weather data (air temperature, relative humidity, wind speed, radiation) in 10 Minutes measuring interval and the ASCE Penman-Monteith equation (Walter et al. 2005) for short time steps. During the evaluation period (July, 10th-July, 15th 2006) there is no difference between compared results. At part (b) of Fig. 4 a precipitation event on July, 10th 2006 with a total amount of up to $4 \mathrm{~mm}$ of rainfall between 11:30 A.M. and 1:30 P.M. is figured out. Precipitation has been measured using a tipping bucket with a resolution of $0.1 \mathrm{~mm}$ at the one hand and has been determined from lysimeters weight following the procedure in Fig. 2. Nearly no difference is visible between the two cumulative curves; due to the continuous reading of weights the determination from lysimeter data shows a better resolution in time periods with low rainfall intensity.
Fig. 4 Accuracy of water balance parameters determined from precise weighing Lysimeter data. a measured and calculated grass-reference evapotranspiration. b Precipitation determined from Lysimeter weights and measured using a tipping bucket
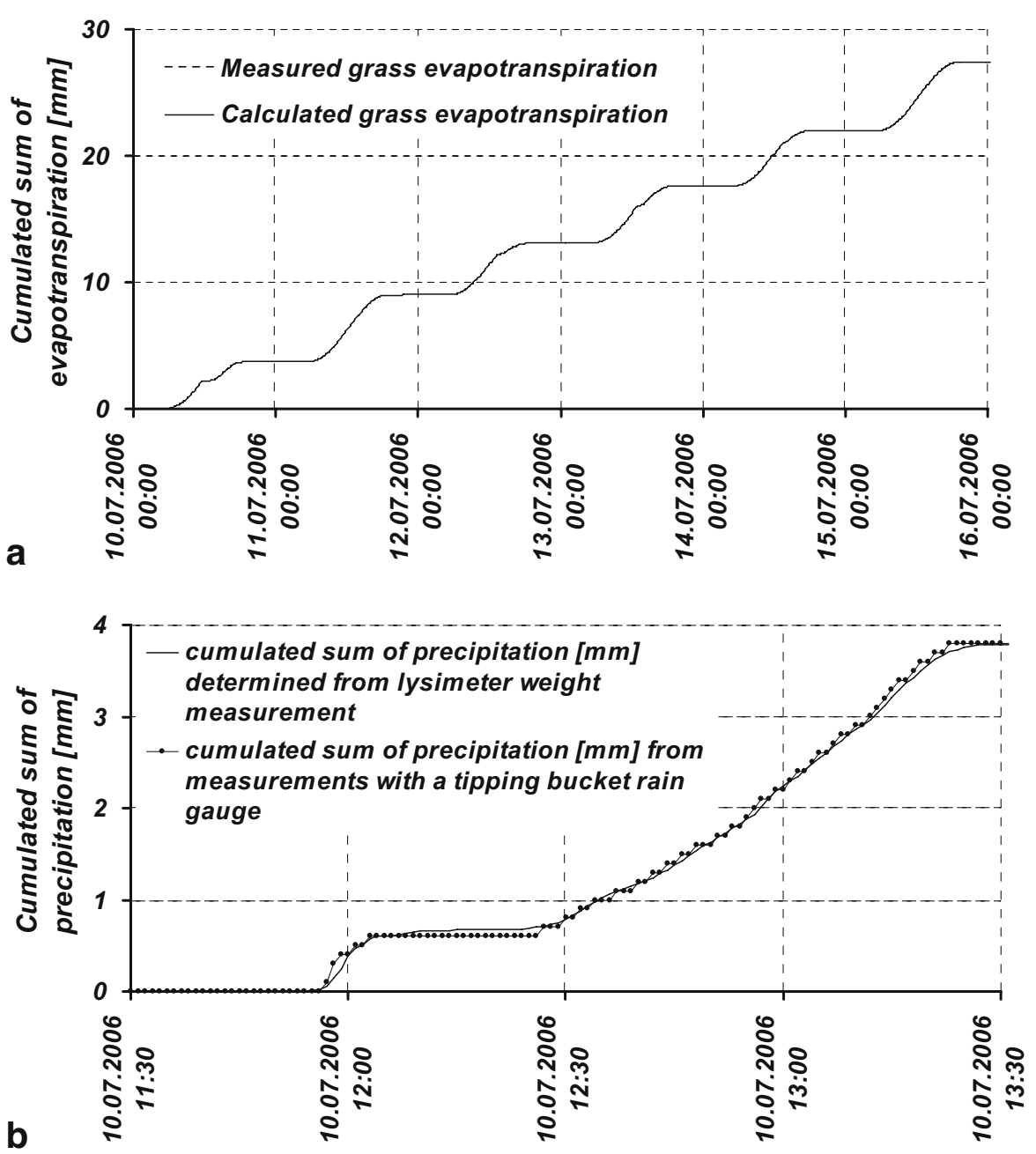
The weight readings represent directly snowfall, measuring the water equivalent of snow. The measure of snow causes problems, as snow crystals builds up share forces after self compaction. To prevent this, we cut the snow bridge crossing the gap between lysimeter and surrounding area to keep on going with correct weight measurement after the snow event. This is of course a problem in mountain regions or non-personal serviced sites.

\subsection{Meteorological Lysimeter}

The meteorological Lysimeter as shown in Fig. 5 is made to determine ET, ET $_{\mathrm{o}}$, Drainage and precipitation from Lysimeter weight data and from measured meteorological data.

Dimension, drainage system and drainage water measurement is done as described at Hydro-Lysimeter. In addition it measures soil water content and temperature in coherence with climatic data. Soil temperature is measured in depths of 5,10 and $20 \mathrm{~cm}$. Soil water content is measured at $10 \mathrm{~cm}$ below surface. Further a weather station is equipped with a radiation sensor and sensors for relative humidity and wind speed at $2 \mathrm{~m}$, and air temperature sensors at $5 \mathrm{~cm}, 50 \mathrm{~cm}$ and $2 \mathrm{~m}$.

Meteorological parameters may be used for the calculation of the ASCE standardized reference evapotranspiration equation (Walter et al. 2005) for short time interval. Combining measured real evapotranspiration from Lysimeter weight data and calculated grass reference evapotranspiration from meteorological data, crop coefficients (Kcb - transpiration coefficient, $\mathrm{Ke}$ - evaporation coefficient) and water stress coefficients (Ks) may be determined (Allen et al. 1998). After determination of the crop coefficients it is possible to split real evapotranspiration into the components evaporation $\left(\mathrm{ET}_{0} \times \mathrm{Ke}\right)$ and transpiration $\left(\mathrm{ET}_{0} \times \mathrm{Kcb}\right)$ and to calculate water stress $\left(\mathrm{ET}_{0} \times \mathrm{Ks}\right)$ for the investigated plant. In Fig. 6 this splitting at the Hydro-Lysimeter at research station Wagna for the period May, 15th 2006 May, 15th 2007 is figured out.

The vegetation at the Lysimeter was grass, which was cut every week to a length of $12 \mathrm{~cm}$ for the evaluation of

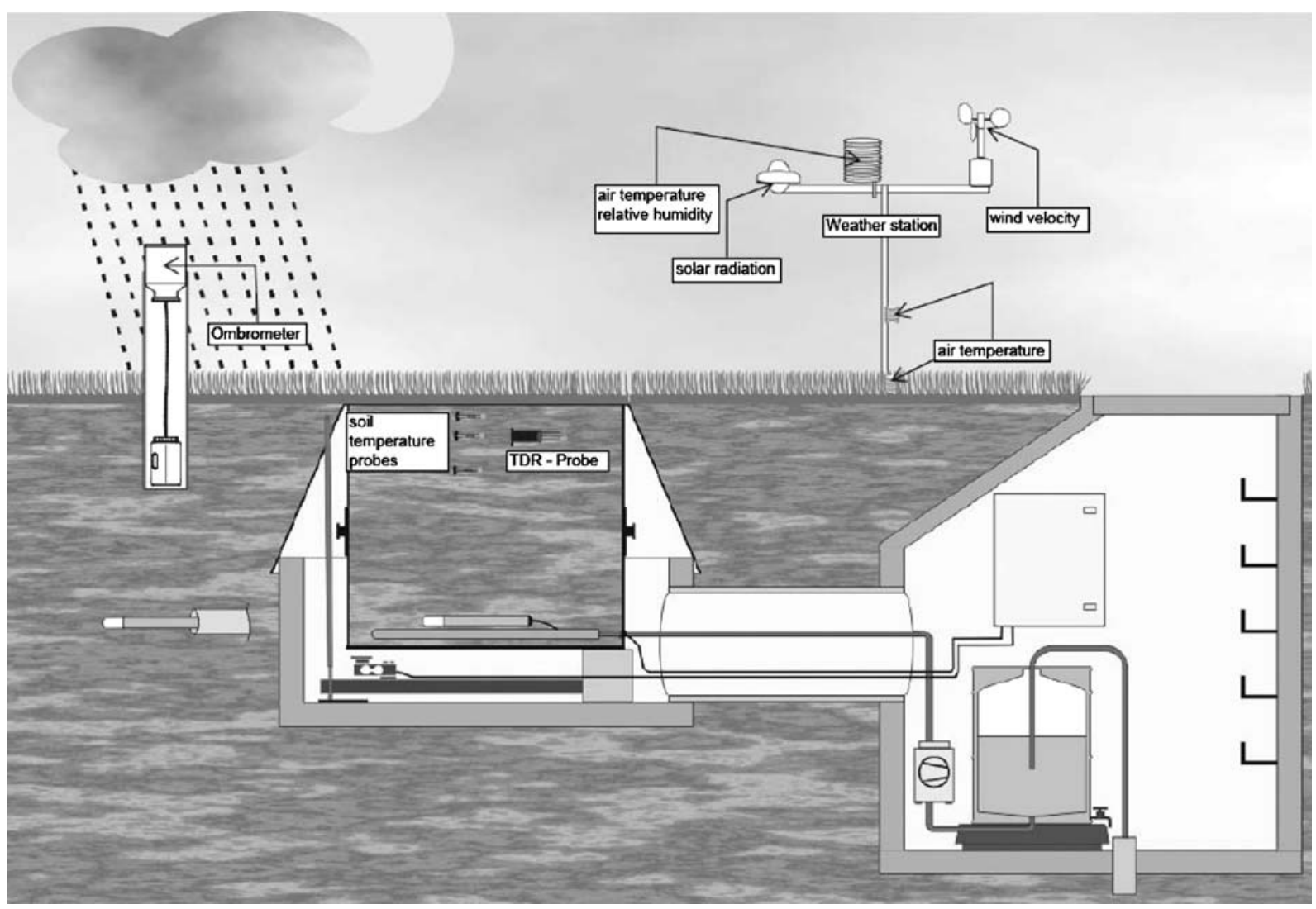

Fig. 5 Schematic sketch of the Meteorological-Lysimeter configuration 
Fig. 6 Determination of the different components of evapotranspiration at Wagna-Hydrolysimeter for the period May, 15th 2006 May 15th 2007

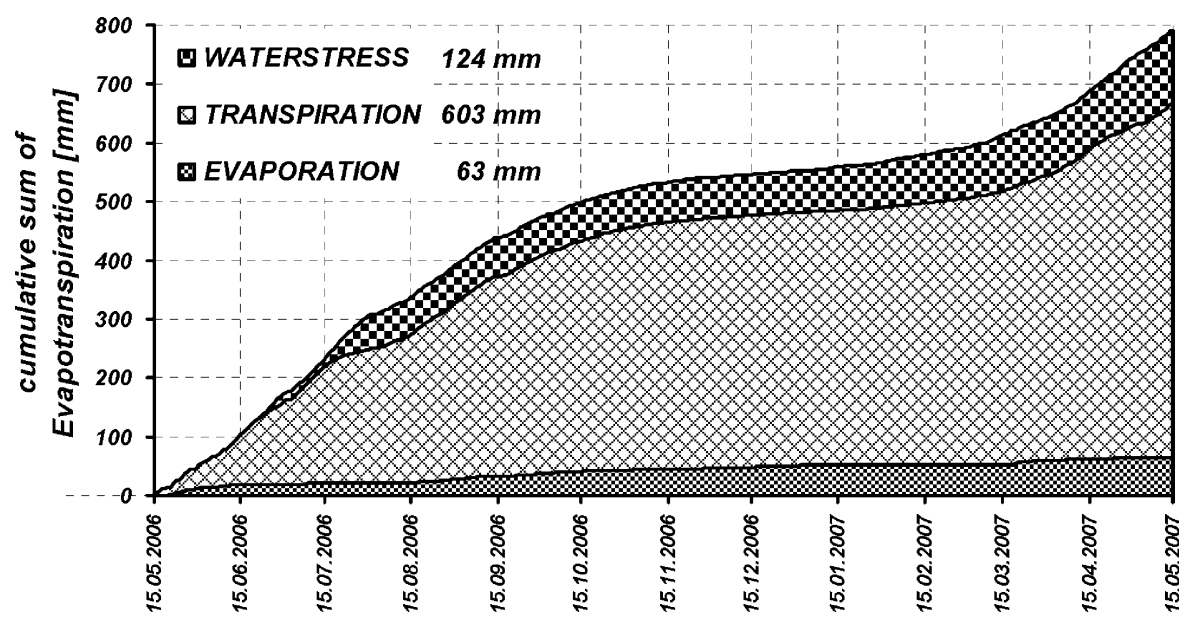

the parameters in the Penman-Monteith equation as presented by Walter et al. (2005). For the 1-year evaluation period the potential reference evapotranspiration at a sandy to gravely soil with a thin loamy to sandy cover $(20 \mathrm{~cm})$ was measured to $792 \mathrm{~mm}$. Water stress led to a reduced real evapotranspiration of $666 \mathrm{~mm}$, where $63 \mathrm{~mm}$ has been evaporated and $603 \mathrm{~mm}$ has been transpired by the grass vegetation.

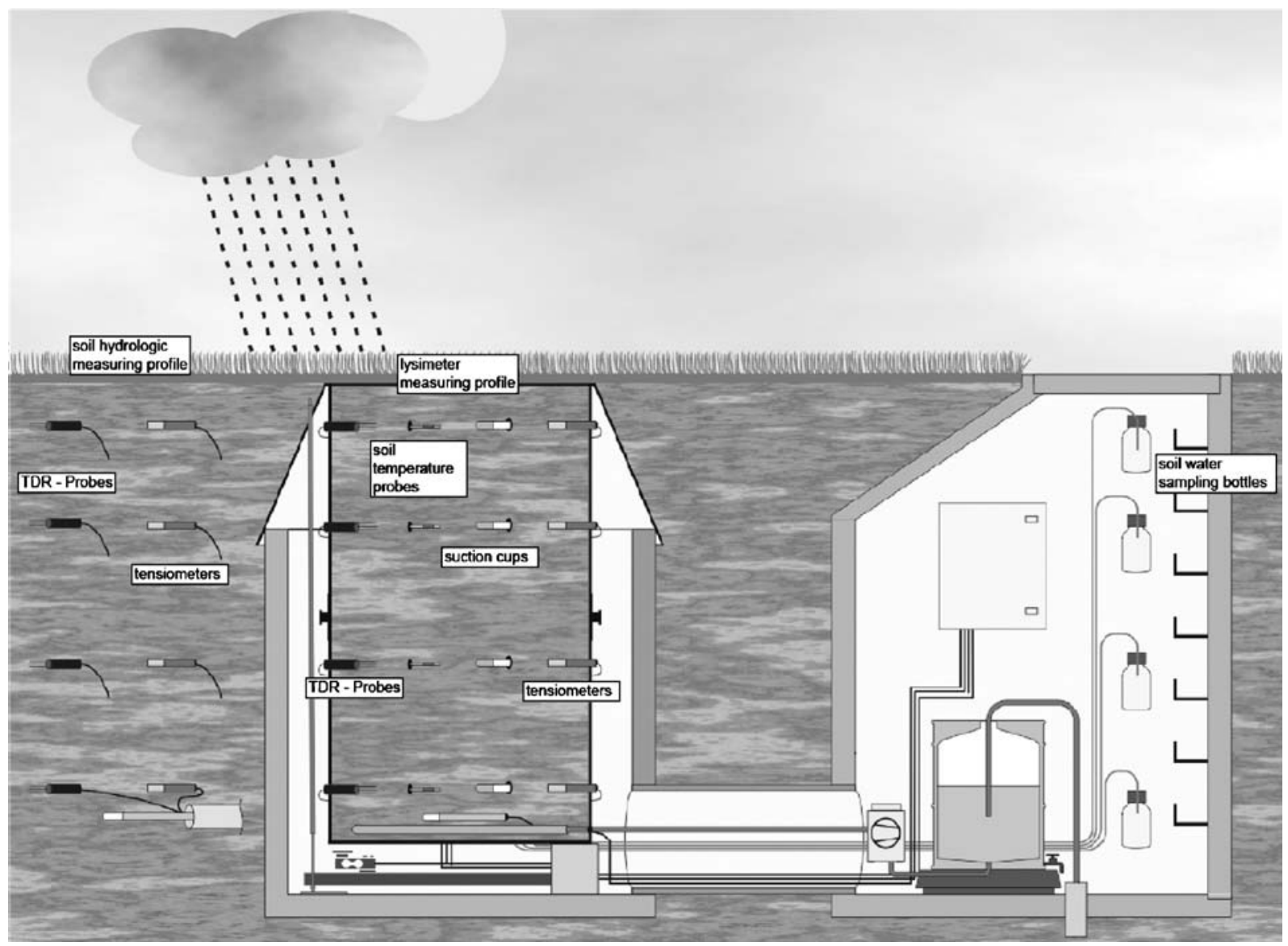

Fig. 7 Schematic sketch of the Scientific Field-Lysimeter configuration 
Table 1 Comparison of mean monthly soil temperature data in different depth (b. S.=below Surface) of the Lysimeter in Wagna and corresponding depths in the surrounding field for the year 2006

\begin{tabular}{|c|c|c|c|c|c|c|c|c|}
\hline \multirow[t]{2}{*}{2006} & \multicolumn{2}{|l|}{$35 \mathrm{~cm} \mathrm{b.} \mathrm{S.}$} & \multicolumn{2}{|l|}{$60 \mathrm{~cm} \mathrm{b.} \mathrm{S.}$} & \multicolumn{2}{|c|}{$90 \mathrm{~cm} \mathrm{~b} . \mathrm{S}}$. & \multicolumn{2}{|c|}{$180 \mathrm{~cm} \mathrm{b.} \mathrm{S}$} \\
\hline & Lysimeter & Field & Lysimeter & Field & Lysimeter & Field & Lysimeter & Field \\
\hline January & 1.38 & 1.18 & 2.10 & 2.13 & 2.10 & 3.05 & 3.32 & 5.59 \\
\hline February & 0.24 & 0.56 & 0.79 & 1.33 & 0.79 & 2.05 & 2.00 & 4.25 \\
\hline March & 3.18 & 2.53 & 2.97 & 2.66 & 2.97 & 2.85 & 2.94 & 4.10 \\
\hline April & 10.69 & 10.48 & 9.85 & 9.70 & 9.85 & 8.94 & 7.66 & 7.60 \\
\hline May & 15.75 & 15.79 & 14.88 & 14.93 & 14.88 & 14.01 & 12.07 & 11.70 \\
\hline June & 19.17 & 18.99 & 17.91 & 17.76 & 17.91 & 16.63 & 14.51 & 14.02 \\
\hline July & 21.38 & 22.02 & 20.61 & 20.95 & 20.61 & 19.84 & 17.56 & 17.03 \\
\hline August & 18.15 & 18.92 & 18.17 & 18.96 & 18.17 & 18.79 & 17.16 & 7.49 \\
\hline September & 16.34 & 16.76 & 16.32 & 16.83 & 16.32 & 16.82 & 15.73 & 16.31 \\
\hline October & 13.87 & 14.25 & 14.00 & 14.60 & 14.00 & 14.85 & 13.86 & 15.03 \\
\hline November & 8.00 & 8.02 & 8.74 & 9.19 & 8.71 & 0.23 & 9.75 & 12.16 \\
\hline December & 4.30 & 4.62 & 5.34 & 5.84 & 5.34 & 6.92 & 6.53 & 9.30 \\
\hline Yearly mean & 11.04 & 11.18 & 10.97 & 11.24 & 10.97 & 11.25 & 10.26 & 11.21 \\
\hline
\end{tabular}

\subsection{Scientific Field Lysimeter}

This type of Lysimeter is designed as the HydroLysimeter but with a depth of $2 \mathrm{~m}$. In addition to the Hydro-Lysimeter readings and water samples are taken from monolith horizons under field conditions to describe the freights and fluxes also inside the soil profile from $10 \mathrm{~cm}$ down to $180 \mathrm{~cm}$ (Fig. 7).

Completed by sensors and sampling devices in depths of $10,30,90$ and $180 \mathrm{~cm}$ depths. The added measurement of the volumetric water content, matrix potential (using tensiometers) and temperature allows describing soil water and fluxing situation stepwise down the monolith. Normally the measurements in the Lysimeter monolith is supplemented by sensor readings in a soil hydrologic measurement profile in the undisturbed field to investigate the significance of the Lysimeter investigations in comparison to natural field conditions. In combination with suction cups and tension controlled vacuum for pore water extraction at depths of 10, 30, 90 and $180 \mathrm{~cm}$, the solute load, metabolisms or contamination inside the monolith results in transparency of chemical interactions. Therefore, this kind of lysimeter is suited for soil and water research, or risk assessment or bio remediation of wasted soils.

Two scientific field Lysimeters are installed at the Wagna agricultural test field, comparing conventional and organic farming. Table 1 shows monthly mean soil temperature data in 35, 60, 90 and $180 \mathrm{~cm}$ below surface comparing measurements in the Lysimeter
Fig. 8 Downward movement of the infiltration front of a precipitation event on a Lysimeter indicated from measurements of soil water tension

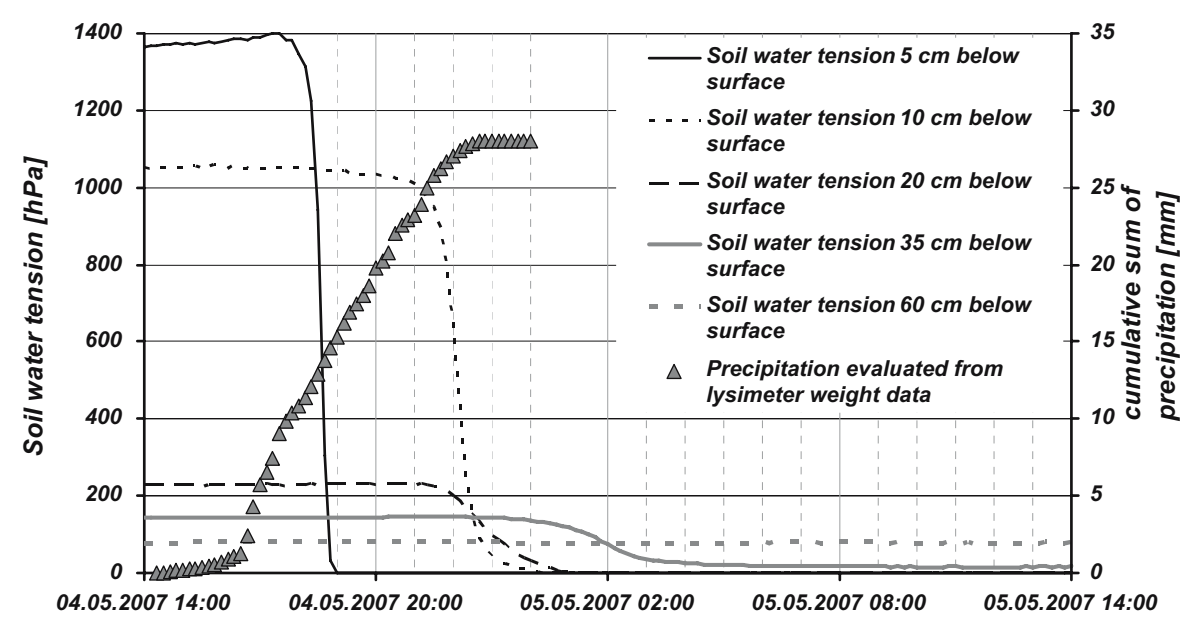




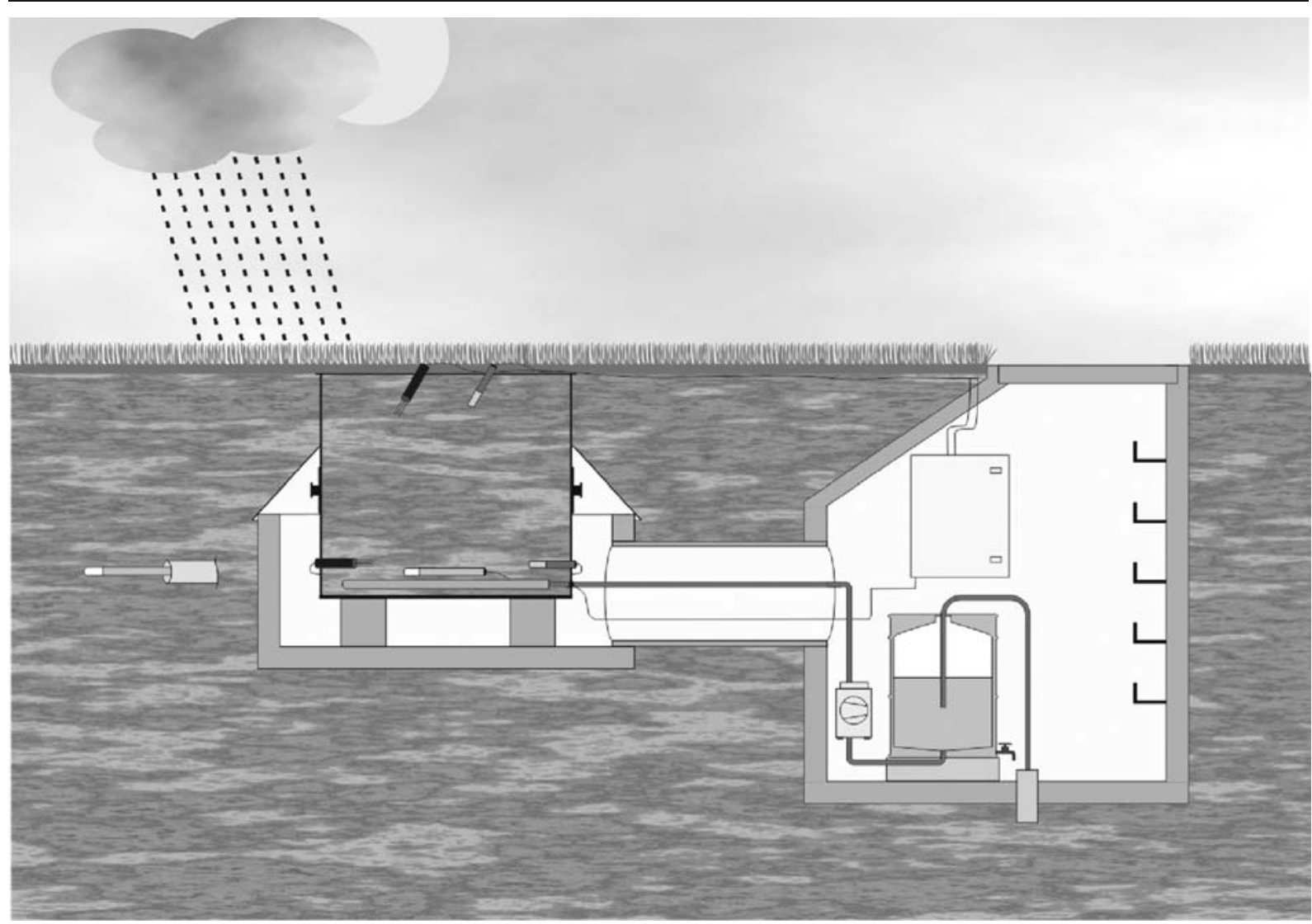

Fig. 9 Schematic sketch of the Agro-Lysimeter configuration

monolith and in the soil hydrologic profile in the undisturbed field beneath the Lysimeter (conventional farming). The comparison of the data sets show only low differences in temperature and indicate a high significance of Lysimeter data. The influence of the Lysimeter construction on soil temperature is very low.

In Fig. 8 the data of the soil water tension sensors in different depths of the Lysimeter with organic farming are used to investigate the infiltration of water from a rainfall event on May, 4th 2007 in the upper horizons of the soil profile. The infiltration front moves downward to $35 \mathrm{~cm}$ in a few hours but does not arrive at the measuring depth of $60 \mathrm{~cm}$.

\subsection{Agro-Lysimeter}

The Agro-Lysimeter is designed to measure root water stress, drainage water amount and solute flux under field conditions of a commonly cultivated field. The monolithic cylindrical stainless steel Lysimeter has a surface of $1 \mathrm{~m} 2$ and a monolith depth of $1 \mathrm{~m}$. The upper ring with a height of $35 \mathrm{~cm}$ is removed to cultivate the field and mounted after tillage. The field matrix potential in $90 \mathrm{~cm}$ depth is transferred into the lysimeter by the suction cup rake with an active surface of 3,600 $\mathrm{cm} 2$, as described at the Hydro-Lysimeter.

Table 2 Solute leaching measured at two Agro-Lysimeters with different agricultural management systems (Wagna agricultural test field). SW=Seepage Water amount

Solute leaching 01.01.2005 bis 31.12.2005

\begin{tabular}{llll}
\hline Parameter & Unit & $\begin{array}{l}\text { Conventional } \\
\text { farming }\end{array}$ & $\begin{array}{l}\text { Organic } \\
\text { farming }\end{array}$ \\
\hline $\begin{array}{l}\text { cum. Sum of SW } \\
\text { mean value of el. cond. } \\
\text { mean value of pH }\end{array}$ & $\mu \mathrm{mm} \mathrm{cm}{ }^{-1}$ & 310 & 364 \\
$\begin{array}{l}\text { Leaching } \\
\text { Sodium }\end{array}$ & - & 7.35 & 480 \\
Potassium & $\mathrm{kg} \mathrm{ha}^{-1}$ & 26.65 & 7.42 \\
$\begin{array}{l}\text { Magnesium } \\
\text { Calcium }\end{array}$ & $\mathrm{kg} \mathrm{ha}^{-1}$ & 3.59 & 22.30 \\
Chloride & $\mathrm{kg} \mathrm{ha}^{-1}$ & 17.74 & 2.65 \\
Nitrate & $\mathrm{kg} \mathrm{ha}^{-1}$ & 197.36 & 20.38 \\
Sulphate & $\mathrm{kg} \mathrm{ha}^{-1}$ & 52.68 & 293.86 \\
$\mathrm{~kg} \mathrm{ha}^{-1}$ & 161.80 & 240.51 \\
& $\mathrm{~kg} \mathrm{ha}^{-1}$ & 134.25 & 174.42 \\
\hline
\end{tabular}


Contrary to the other Lysimeters described the AgroLysimeter is not weighable (Fig. 9). Additional sensors may be adjusted in the upper soil horizon.

The amount of seepage water is detected using a $0.1 \mathrm{~mm}(100 \mathrm{ml})$ capsulated tipping bucket. A defined volume of seepage water (normally $3.5 \mathrm{vol} . \%$ ) is filled directly in a sampling bottle, where the same tension is hold as measured in the field. Cumulative samples over longer observation periods (for example 1 month) can be taken without any contact of the seepage water with air.

Because the Lysimeter is not weighable, and seepage water detection is done with a tipping bucket instead of a balance the Agro-Lysimeter is much cheaper than the other Lysimeter types. It is best suited for recurrent monitoring of groundwater recharge and solute leaching from arable land as shown in Table 2.

\section{Summary and Conclusions}

With this paper we wanted to introduce the general requirements for lysimeter stations and their operation, the technical conception, operation and quality control. Beside the specific needs of design and setup of lysimeter stations, there is need to define general requirements to enable comparable results based on standardized basic design and to reduce individual mistakes. First, lysimeters only cover one scale of scientific or applied research working level, which is suited between laboratory scale and field scale. They combine the advantages of true field conditions and laboratory possibilities of varying parameters, handling and maintenance. The advantage of a defined surface and volume includes the disadvantage of having only a certain surface and certain volume, which may not cover field heterogeneity.

Due to the specific needs of each application the instrumentation varies. To prevent backwater at the lysimeters bottom all lysimeters described are instrumented with a tool to transfer field matrix potential into the Lysimeter. Seepage water is sampled by a suction cup rake at the lysimeters bottom. If water balance is the only aim, the Hydro-Lysimeter measures drainage, precipitation and evapotranspiration may be determined from the measurements of the lysimeters weight change. Additional field sensors may be useful to verify results over areas and regions. For infiltration determination, matrix potential sensors and water content probes are installed in several depths. For solute transport studies suction cups are installed. The new lysimeter setups follow up the fact that micro organisms interact in the rhizosphere with high dependencies on water, fluxes, temperature and chemical environment. Therefore precision monolith lysimeters offer specific microorganism approach.

\section{References}

Allen, R. G., Pereira, L. S., Raes, D., \& Smith, M. (1998). Crop Evapotranspiration (guidelines for computing crop water requirements). FAO Irrigation and Drainage Paper No. 56, $300 \mathrm{P}$.

Fank, J., Stenitzer, E., Feichtinger, F., \& Cepuder, P. (2004). Messdaten und Modellkalibration an der Forschungsstation Wagna und daraus abzuleitende Anforderungen an Messstellen zur Kalibration von Bodenwasserhaushalts- und Stofftransportmodellen. In: Klotz, D. (Hrsg.): Untersuchungen zur Sickerwasserprognose in Lysimetern. GSF-Bericht 02/04, 79-86, München.

Fank, J., \& Unold, G. v. (2005). Wägbare monolithische Lysimeter unter maschineller Freilandbewirtschaftung (Wagna - Austria). 11. Gumpensteiner Lysimetertagung "Lysimetrie im Netzwerk der Dynamik von Ökosystemen" vom 5.-6. April 2005, 55-60, Gumpenstein.

Fank, J. (2006). Modellkalibration anhand von Lysimeterdaten. Wissenschaftliche Tagung 2006 Sektion Lysimeter, Landwirtschaft und Landschaftspflege in Thüringen, Heft 10/ 2006, 37-49, Jena.

Klocke, N. L., Todd, R. W., Hergert, G. W., Watts, D. G., \& Parkhurst, A. M. (1993). Design, installation, and performance of percolation lysimeters for water-quality sampling. Transactions of the ASAE, 36, 429-435.

Meissner, R., Seeger, J., Rupp, H., Seyfarth, M., \& Borg, H. (2007). Measurement of dew, fog, and rime with a highprecision gravitation Lysimeter. Journal of Plant Nutrition and Soil Science, 170, 335-344 2007.

Meissner, R., \& Seyfarth, M. (2004). Measuring water and solute balance with new Lysimeter techniques. In B. Singh (Ed.) Proceedings of the 3rd Australian and New Zealand Soils Conference, Sydney, Australia, 5-9 December 2004 (pp. 151-8.). Australia: The Regional Institute Ltd, Gosford.

Walter, I. A., Allen, R. G., Elliott, R., Itenfisu, D., Brown, P., Jensen, M. E., et al. (2005). The ASCE standardized reference evapotranspiration equation. ASCE-EWRI Task Committee Report.

Wriedt, G. (2004). Modelling of nitrogen transport and turnover during soil and groundwater passage in a small lowland catchment of Northern Germany. Ph.D. thesis, University of Potsdam, Germany.

Young, M. H., Wierenga, P. J., \& Mancino, C. F. (1996). Large weighing lysimeters for water use and deep percolation studies. Soil Science, 161, 491-501. 